\title{
Development of Downy Mildew-resistant Cucumbers for Late-season Production in the Northeastern United States
}

\author{
William L. Holdsworth \\ Department of Plant Breeding and Genetics, Cornell University, 248 \\ Emerson Hall, Ithaca, NY 14853
}

Carly F. Summers

Department of Plant Pathology and Plant-Microbe Biology, Cornell University, 630 West North Street, Geneva, NY 14456

\section{Michael Glos}

Department of Plant Breeding and Genetics, Cornell University, 248 Emerson Hall, Ithaca, NY 14853

\section{Christine D. Smart}

Department of Plant Pathology and Plant-Microbe Biology, Cornell University, 630 West North Street, Geneva, NY 14456

\author{
Michael Mazourek ${ }^{1}$ \\ Department of Plant Breeding and Genetics, Cornell University, 248 \\ Emerson Hall, Ithaca, NY 14853 \\ Additional index words. breeding, Cucumis sativus, cucurbit, disease resistance, oomycete, \\ Pseudoperonospora cubensis
}

\begin{abstract}
Cucurbit downy mildew, a disease caused by the oomycete pathogen Pseudoperonospora cubensis (Berk. \& Curt.) Rostov., is a serious threat to cucumber (Cucumis sativus L.) production worldwide and can result in $100 \%$ yield losses in affected environments. In the last decade, strains of the pathogen have overcome the resistance of commercial cultivars in the United States, and currently no cultivar has robust resistance to the disease. This lack of resistance has been especially problematic for cucumber growers seeking to capture the late-season market, when downy mildew is ubiquitous throughout Eastern and Great Lakes production environments. Our objectives were to identify sources of resistance genes and to introgress these genes into high-quality, high-yielding breeding material. Using the moderately resistant cucumber cultivars Marketmore 97 and Ivory Queen as well as the Cornell-developed cultivars Platinum and Salt \& Pepper, we have developed lines with excellent disease resistance. In a trial of 27 lines that included Cornell breeding material and the most resistant cultivars and U.S. Department of Agriculture (USDA) accessions identified in previous studies, the Cornell breeding line DMR-NY264 had the highest level of downy mildew resistance and the highest yields under disease pressure. In New York, plants of DMR-NY 264 produced fruit until frost without fungicide application.
\end{abstract}

Received for publication 22 July 2013. Accepted for publication 4 Nov. 2013.

Support for William Holdsworth was provided by USDA National Institute of Food and Agriculture Plant Breeding and Education Grant No. 2010-85117-20551. Support for Carly Summers was provided by NSF Grant No. DGE-1144153. Funding was provided by the Toward Sustainability Foundation, the Cornell Vegetable Breeding Institute, and USDA National Institute of Food and Agriculture Organic Agriculture Research \& Extension Initiative Grant No. 2012-02292.

We thank Maryann Fink-Brodnicki, Nick Vail, Jessica Leonard, Sam Malriat, Paige Roosa, Scott Anthony, Gregory Inzinna, Steve McKay, Jim Ballerstein, Eric Cerretani, Jason Grauer, Jenny Moore, Myra Manning, John Jantz, and Steve Reiners for technical assistance. We thank Yiqun Weng, University of Wisconsin, USDA-ARS, for contributing seed of WI lines.

${ }^{1}$ To whom reprint requests should be addressed; e-mailmm284@cornell.edu. the fifth largest vegetable crop worldwide measured by production volume with 65.3 million metric tonnes harvested in 2011 (FAOSTAT, 2013). The United States is the fifth largest producer of cucumber, and in 2012, 901,000 metric tonnes of fresh market and pickling cucumbers were grown on nearly 55,000 ha for a combined value of $\$ 421$ million (USDA, 2008, 2013).

Symptoms of downy mildew occur on foliage. Characteristic symptoms on cucumber include angular-shaped chlorotic lesions that appear on adaxial leaf surfaces from 4 to $12 \mathrm{~d}$ post-inoculation (Lebeda and Cohen, 2011; Palti and Cohen, 1980). Warm days (25 to $\left.30^{\circ} \mathrm{C}\right)$ and $\operatorname{cool}\left(10\right.$ to $\left.15^{\circ} \mathrm{C}\right)$ humid nights that are typical of many cucumber-producing regions in the eastern United States promote symptom development and pathogen colonization, respectively (Cohen and Eyal, 1977; Lebeda and Cohen, 2011). Under these conditions, chlorotic lesions may become necrotic, coalesce, and lead to whole-plant death in a matter of weeks. Within 4 to $10 \mathrm{~d}$ of the first disease symptoms, sporulation may be observed on abaxial leaf surfaces by the presence of sporangia-bearing sporangiophores that give the leaves a characteristic purplish gray "downy" appearance (Lebeda and Cohen, 2011; Palti and Cohen, 1980). The pathogen is spread on wind currents from areas where the pathogen overwinters and can travel for hundreds of kilometers (Lebeda and Cohen, 2011); in the eastern United States, sporangia arrive from Florida or greenhouses around the Great Lakes (Call et al., 2013; Nusbaum, 1944). Avoidance or exclusion of cucurbit downy mildew in field environments is therefore not possible in the eastern United States.

For decades, downy mildew on cucumbers in the United States was effectively managed with genetic host resistance and was not a major production concern (Call et al., 2013; Holmes et al., 2006). Severe cucumber yield losses in the early decades of the 20th century prompted the first breeding effort to incorporate downy mildew resistance into elite cucumber lines in 1939, when J.M. Jenkins of South Carolina crossed the moderately resistant cultivars Chinese Long and Puerto Rico No. 37 with the high-quality commercial cultivars A \& C and Colorado (Barnes, 1961; Barnes et al., 1946; Jenkins, 1942; Stewart, 1897). Over the next several decades, a number of new downy mildewresistant lines were released by public breeding programs, including cultivars in the 'Marketmore' and 'Poinsett' series, which featured prominently in the pedigrees of many subsequent fresh-market cultivars (Barnes, 1948; Cavatorta et al., 2007; Clark et al., 1996; Peterson et al., 1982, 1985, 1986). Most of these lines contained mono- or oligogenic resistance derived from 'Chinese Long' and/ or PI 197087 (Barnes and Epps, 1954; Cavatorta et al., 2007; Munger, 1993; Peterson, 1975; Sitterly, 1972; van Vliet and Meysing, 1974). Other sources of resistance originating in China, Japan, and India have been identified but to date have not been used extensively in breeding programs (Call, 2012; Call 
et al., 2012b; Cochran, 1937; Criswell, 2008; Duran et al., 2009; Klosinska et al., 2010; Neykov and Dobrev, 1982; Zhang et al., 2013).

The resistance of commercial cultivars in the United States was defeated in 2004 when a new strain of $P$. cubensis emerged in southern states (Holmes et al., 2006). In some production environments, growers experienced 95\% to $100 \%$ yield loss (Colucci et al., 2006; Savory et al., 2011), leading to substantial economic losses, including \$16 million in North Carolina alone during the 2004 epidemic (Colucci et al., 2006; Colucci and Holmes, 2010). The use of fungicides now provides limited protection for some cultivars with marginal resistance, although fully susceptible varieties die quickly even under intense fungicide regimes (Call et al., 2013; McGrath et al., 2010). In many northern areas, organic cucumber growers and those harvesting in the late season have responded to the disease by ceasing production entirely after downy mildew moves into their local areas (Northeast Organic Farming Association-New York Winter Conference Growers Roundtable, 2013, personal communication). Recent studies have found that no commercial cultivar or accession from the USDA plant collection has a level of resistance that approaches the pre2004 levels of most commercial cultivars (Call et al., 2012a; Call and Wehner, 2010). In the United States, research and development of downy mildew resistance in cucumber has been ranked the number one research priority by public and private cucumber breeders as well as personnel involved with the cucumber industry (Weng, 2009).

The objective of this research was to address the need for immediate and durable downy mildew resistance in commercial cucumber cultivars. To this end, we initiated a cucumber breeding program to identify novel sources of resistance and combine them into high-yielding, high-quality breeding lines. We trialed these lines against existing cultivars and accessions to evaluate their resistance to downy mildew in New York and to assess their yield during growing periods with and without disease.

\section{Materials and Methods}

Breeding. Breeding activities took place between 2008 and 2013 at Cornell University research facilities. Field evaluations were conducted at the East Ithaca, Varna, and Freeville research farms located in or near Ithaca, NY, as well as the New York State Agricultural Experiment Station Fruit and Vegetable Farm in Geneva, NY. Plants in the field were grown on raised beds $10 \mathrm{~cm}$ high, $76 \mathrm{~cm}$ wide, and $2.0 \mathrm{~m}$ apart. Beds were covered with 0.0254-mm black embossed plastic mulch (Belle Terre Irrigation, Sodus, $\mathrm{NY})$ and irrigated with drip tape $(30-\mathrm{cm}$ emitter spacing and $0.056 \mathrm{~L} \cdot \mathrm{m}^{-1} \cdot \mathrm{min}^{-1}$; Toro Aqua-Traxx; Belle Terre Irrigation, Sodus, $\mathrm{NY}$ ). For the East Ithaca, Varna, and Geneva sites, $10 \mathrm{~N}-8.7 \mathrm{P}-16.6 \mathrm{~K}$ fertilizer was applied before planting at a rate of $336 \mathrm{~kg} \cdot \mathrm{ha}^{-1}$ (Arrow; Royster-Clark, Princeton, NC). At the Freeville Organic Research Farm, compost $(2.4 \mathrm{~N}-1.25 \mathrm{P}-0.9 \mathrm{~K})$ was applied to the field at a rate of $22.4 \mathrm{t} \cdot \mathrm{ha}^{-1}$ before planting. For all conventional sites, soluble fertilizer (Peters 10N-13.1P-16.6K; JR Peters, Inc., Allentown, PA) was applied at transplant at an approximate rate of $1.03 \mathrm{~L} \cdot \mathrm{m}^{-1}\left(2.1 \mathrm{~g} \cdot \mathrm{L}^{-1}\right.$ water). At the Freeville Organic Research Farm, Neptune's Harvest fish emulsion (Hydrolyzed Fish 2N-4P-1K; Neptune's Harvest, Gloucester, MA) was applied immediately after transplanting at an approximate rate of $5.34 \mathrm{~g} \cdot \mathrm{m}^{-1}$. Before transplanting, seedlings were treated with imidacloprid (Marathon II; OHP, Inc., Mainland, PA) and azoxystrobin (Heritage; Syngenta Crop Protection LLC, Greensboro, NC) at the labeled rates to control for cucumber beetles and powdery mildew, respectively.

All pollinations were made in the Guterman Bioclimatic Laboratory and Greenhouse Complex on Cornell's campus using plants that were grown from field-selected cuttings. Plants in the greenhouse were grown in Cornell peat-lite soilless mix (Boodley and Sheldrake, 1982) at $27{ }^{\circ} \mathrm{C}$ day $/ 18{ }^{\circ} \mathrm{C}$ night air temperatures with supplemental lighting and fertilized with 100 ppm of $15 \mathrm{~N}-2.2 \mathrm{P}-12.5 \mathrm{~K}$ Peters Excel CalMag Special fertilizer $5 \mathrm{~d}$ per week (The Scotts Co., Marysville, OH). Cucumber fruit were harvested 6 weeks after pollination and seeds were stored at least 4 weeks to break endodormancy.

We used a pedigree method of selection for our breeding approach as shown in Figure 1. In 2008, the white-skinned, powdery mildewsusceptible cucumber cultivar Ivory Queen was noted as having moderate resistance to downy mildew (Glos, unpublished data). In Winter 2008-09, 'Ivory Queen' was crossed to the Cornell lines 'Platinum' and 'Salt \& Pepper', chosen for their good flavor, high yields, and resistance to multiple diseases, including powdery mildew (Cavatorta et al.,
2012). $F_{1}$ individuals were selfed and backcrossed to 'Ivory Queen' in Spring 2009. In Summer 2009, we evaluated the breeding parents for downy mildew resistance at the East Ithaca Research Farm and the $\mathrm{BC}_{1} \mathrm{~F}_{1}$ and $\mathrm{F}_{2}$ progeny at the Varna Research Farm. We also evaluated additional genotypes in an unreplicated observation trial, including those anecdotally reported to have partial resistance. Resistant $\mathrm{BC}_{1} \mathrm{~F}_{1}$ and $\mathrm{F}_{2}$ individuals were selected in late summer, and stem cuttings of these plants were returned to the greenhouse. In Winter 2009-10, these plants were advanced to the $\mathrm{BC}_{1} \mathrm{~F}_{2}$ and $\mathrm{F}_{3}$ generations, respectively. Additionally, selected $\mathrm{BC}_{1} \mathrm{~F}_{1}$ individuals were backcrossed to the high-quality downy mildew-susceptible parent to regain multiple disease resistances and flavor quality and subsequently advanced to the $\mathrm{BC}_{1} \mathrm{~F}_{2}$ generation. Based on the finding that 'Marketmore 97' had a moderate level of resistance to downy mildew in the observation trial, additional crosses were made between 'Marketmore 97' and 'Ivory Queen' and advanced to the $F_{2}$ generation. In Summer 2010, all of the breeding material was evaluated for resistance at the Varna Research Farm and the most resistant individuals were self-pollinated in Winter 2010-11. In Summer 2011, $\mathrm{BC}_{1} \mathrm{~F}_{2: 3}$ and $\mathrm{F}_{2: 3}$ families were evaluated in three replications at the Freeville Organic Farm. Individual resistant plants were selected from the most resistant families and advanced in Winter 2011-12. In Summer 2012, three replications each of $\mathrm{BC}_{1} \mathrm{~F}_{2: 4}$ and $\mathrm{F}_{2: 4}$ families were evaluated in Geneva. Resistant individuals were selected and selfed in Winter 2012-13.

Field trial location and germplasm. In the summer of 2012, a panel of 27 cultivars, PI accessions, and Cornell $\mathrm{BC}_{1} \mathrm{~F}_{2: 4}$ and $\mathrm{F}_{2: 4}$ breeding lines were evaluated for downy mildew resistance and yield at Cornell University's New York State Agricultural Experiment Station Fruit and Vegetable Farm in

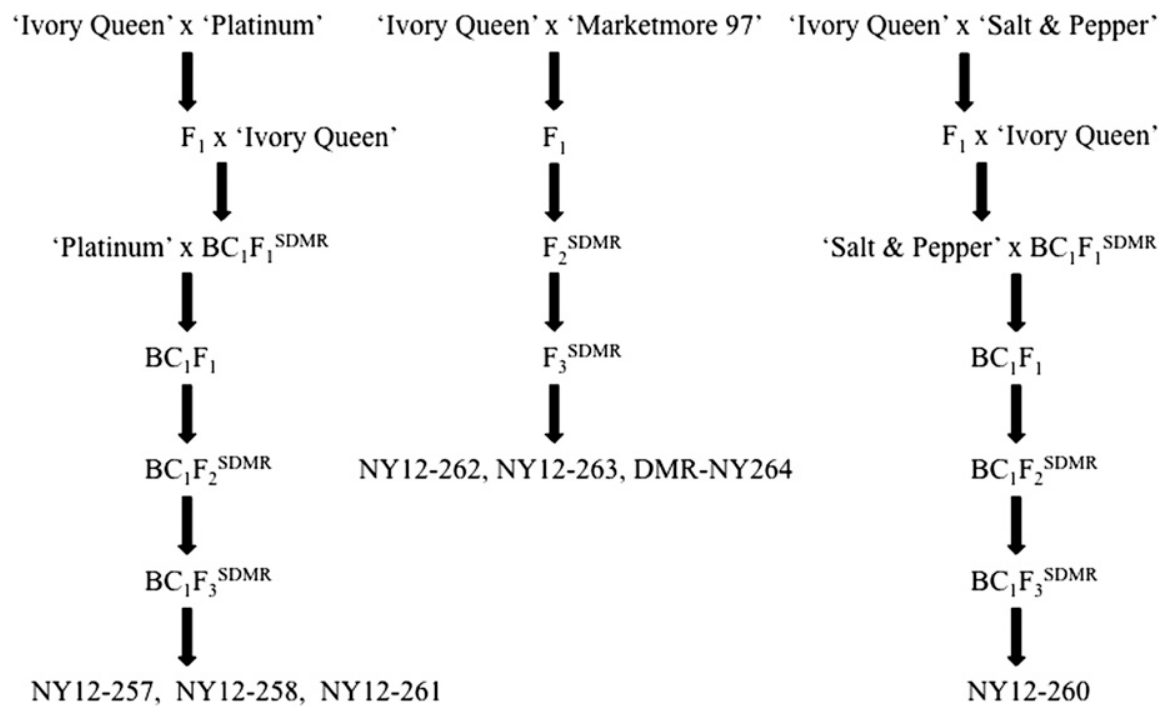

Fig. 1. Pedigrees of downy mildew-resistant Cornell breeding lines NY12-257, NY-1258, NY12-260, NY12-261, NY12-262, NY12-263, and DMR-NY264. ${ }^{\text {SDMR }}$ indicates selection for downy mildew resistance. 
Geneva, NY. Genotypes used and seed sources are listed in Table 1. Genotypes were included based on their reported resistance, susceptibility, popularity, or use in our breeding program. The accession PI 197088 was reported as the most resistant of 1289 lines evaluated in recent trials in North Carolina and Poland, which included most of the USDA collection (Call et al., 2012b; Criswell, 2008); PI 197085 and PI 330628 were also among the top accessions in that study. 'WI 2238' and 'WI 2757' were reported to have the top multilocation and top multiyear, multilocation downy mildew resistance, respectively, of a group of 83 cultivars trialed in North Carolina and Michigan from 2007 to 2009 (Call et al., 2012a). 'Picolino' and 'Straight 8' are known to be susceptible (Mazourek, unpublished data; Call et al., 2012a). 'Diva', 'Dasher II', 'Cross Country', 'Eureka', and 'Fanfare' are common slicing and pickling varieties among conventional and organic growers. 'Marketmore 97', 'Ivory Queen', 'Platinum', and 'Salt \& Pepper' were included because they were breeding parents in our program. Finally, 'Poinsett 76' has historically been a source of downy mildew resistance in commercial cultivars. Trial entries were arranged in six-plant plots that spanned $2.3 \mathrm{~m}$ with $1.8 \mathrm{-m}$ spacing between plots. Plots were replicated three times in a randomized complete block design with the exception of 'WI 2757', which was replicated twice. Growing conditions were identical to those used for the breeding program with the exception that overhead irrigation was used in addition to drip irrigation during weeks without rain to promote leaf moisture conducive for pathogen growth and development.

Field trial resistance ratings. Downy mildew disease ratings were measured on a whole-plot basis after natural disease infection. The first rating was taken when downy mildew was detected in an adjacent field, and ratings were recorded thereafter weekly for 7 weeks until low temperatures became more limiting for cucumber growth and fruit production than disease. Ratings were estimated visually and were recorded as the percentage of foliar area covered in chlorotic and necrotic disease lesions. No distinction was made between these types of lesions, because both types reduce the capacity of the plants for photosynthesis and fruit production and because chlorosis and necrosis have been reported to be highly correlated (Criswell et al., 2008). Plots that were completely killed by downy mildew were rated " $100 \%$." For analysis, disease ratings were represented by the area under the disease progress curve (AUDPC).

Field trial yield evaluation. Yield data were collected as soon as the first genotypes were producing fruit. Fruit were harvested from each plot twice per week and weighed. Fruits were then sorted into marketable and unmarketable classes and counted. Unmarketable fruit included those that were misshapen, scarred, diseased, insect-damaged, or otherwise unsalable. Data were collected 12 times over a total of 6 weeks. Yield data were divided into two time periods: the "early downy period," corresponding to the first 3 weeks of data collection, and the "late downy period," corresponding to the last 3 weeks of data collection.

Greenhouse cotyledon assay-disease inoculation and ratings. In Winter 2012-13, a panel of 30 cucumber lines was evaluated for downy mildew resistance by controlled inoculations in greenhouses at the New York State Agriculture Experiment Station in Geneva, NY. The panel consisted of Cornell breeding lines as well as the $17 \mathrm{PI}$ accessions

Table 1. Cucumber genotypes and seed sources for Summer 2012 field trial and Winter 2013 greenhouse assay in Geneva, NY.

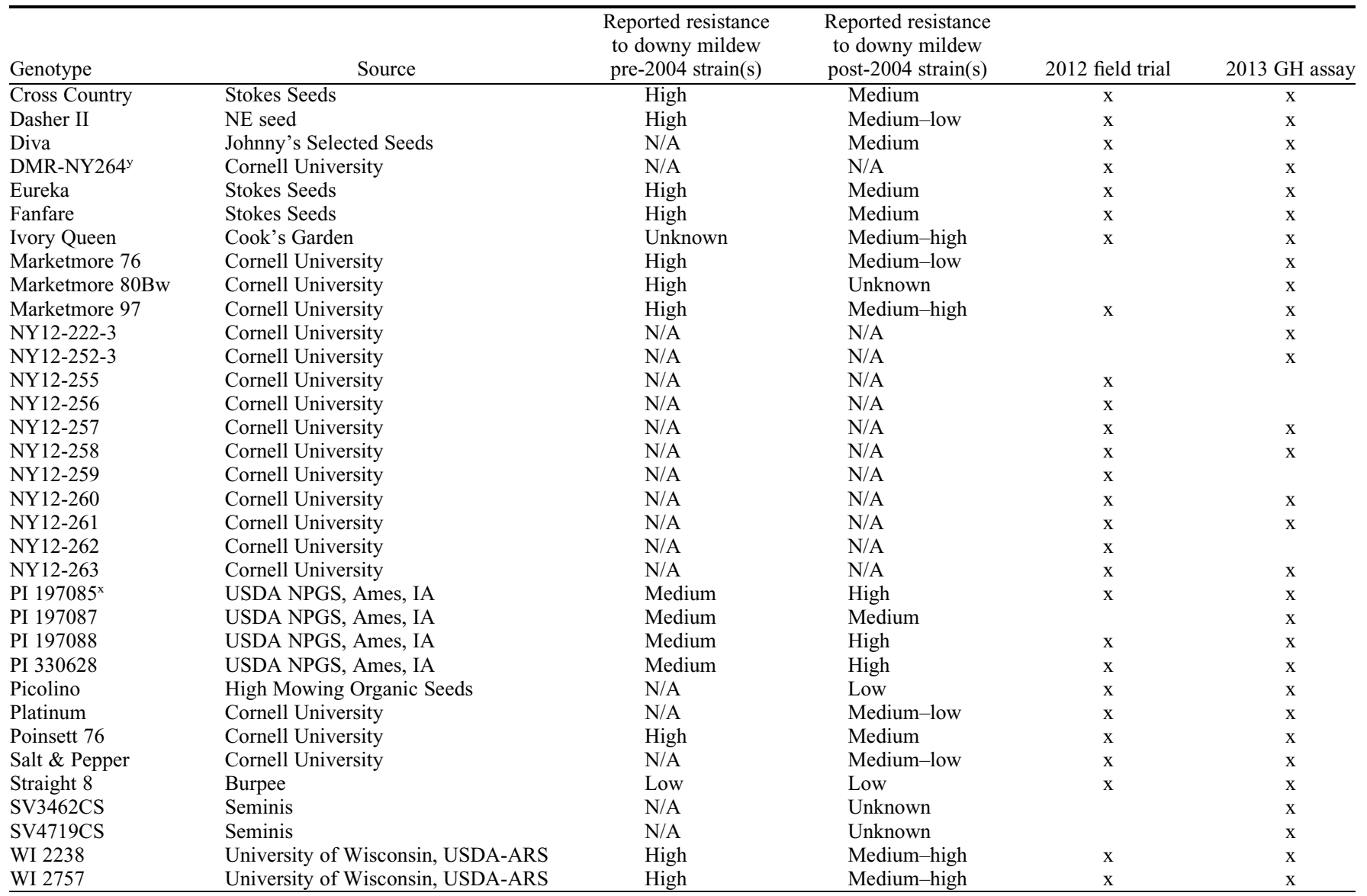

${ }^{\mathrm{z}}$ Reports of genotype resistance to the pre-2004 strain come from unpublished observation data, except for PI accessions, which come from Wehner and Shetty (1997). Quantitative data from these studies are represented qualitatively. Reports of genotype resistance to the post-2004 strain for Cornell lines come from pre2012 unpublished observation data, and all others from Call et al. (2012a, 2012b). Quantitative data from these studies are represented qualitatively.

${ }^{y}$ DMR-NY264 and NY12-2 genotypes are Cornell breeding lines.

${ }^{x}$ PI accessions were selfed twice to ensure homogeneity of seed stock. No morphological variation within a PI accession was observed.

$\mathrm{GH}=$ greenhouse; $\mathrm{N} / \mathrm{A}=$ not applicable. 
and cultivars included in the summer field trial (Table 1). Additionally, the following cultivars and accessions were included: Marketmore 76, Marketmore 80Bw, PI 197087, SV4719CS, and SV3462CS. 'Marketmore 76' and 'Marketmore 80Bw' (bacterial wiltresistant) are open-pollinated, multiple diseaseresistant slicing cultivars with important traits for future breeding efforts. PI 197087 is one of the primary, original sources of downy mildew resistance. SV4719CS and SV3462CS are new releases from Seminis with advertised downy mildew resistance.

Disease was measured on cotyledons on a whole-plot basis in three replications, except for 'WI 2238', which was replicated twice. For each replication, five plants of each genotype were grown in 50-cell flats in a Cornell soilless potting mix (composed of peat, perlite, and vermiculite in a 4:1:1 ratio). Each flat included a susceptible control, 'Straight 8', and a moderately resistant control, 'Marketmore 97'. At 2 weeks postplanting, seedlings were inoculated to runoff with a $5 \times 10^{5}$ sporangia $/ \mathrm{mL}$ suspension of $P$. cubensis that consisted of an equal mixture of four isolates collected near Geneva, NY, in 2012. Inoculated plants were placed in moist chambers at $18{ }^{\circ} \mathrm{C}$ overnight and then moved to the greenhouse and grown at $23.9^{\circ} \mathrm{C}$ day/ $18.3^{\circ} \mathrm{C}$ night air temperatures for a $14-\mathrm{h}$ light/10-h dark photoperiod. Disease incidence (number of diseased plants) and disease severity (percent area of diseased cotyledon tissue per plot) were recorded four times starting $4 \mathrm{~d}$ post-inoculation and ending $8 \mathrm{~d}$ post-inoculation. AUDPC data were calculated for each genotype and divided by the AUDPC of a control variety within that flat to control for variation between flats; this generated a proportion referred to as the AUDPC relative to the control genotype (RaAUDPC) (Hansen et al., 2005; Yuen and Forbes, 2009).

Statistical analysis. R statistical software (R 2.15.3; R Core Team 2013) was used for all analyses. For all data, analyses of variance (ANOVA) were conducted using the "agricolae" package in R (de Mendiburu, 2013). For the Summer 2012 field trial data, separate ANOVA tests were conducted for total number of fruit, total weight of fruit, number of marketable fruit, and AUDPC to determine the effect of genotype on yield and disease. For the Winter 2013 greenhouse data, an ANOVA test was conducted for RaAUDPC data. Following all significant ANOVAs $(P<$ $0.05)$, the Tukey's honestly significant differences (HSD) test (at $\alpha=0.05$ ) was used to separate means.

\section{Results}

Breeding for downy mildew resistance. We have developed a series of green (NY12263, DMR-NY264) and white-skinned (NY12257, NY12-258, NY12-260, NY12-261, and NY12-262) downy mildew-resistant cucumber breeding lines with the parents 'Ivory Queen', 'Marketmore 97', 'Platinum', and 'Salt \& Pepper' using the pedigree method of selection. Pedigrees of these lines are depicted in Figure 1, and pictures of the fruit of DMR-NY264 and NY12-257 are shown in Figure 2. Fruit of NY12-260 are short (3 to 4 ") with black spines; fruit of NY12-261, NY12-262, and NY12-263 are medium-short (4 to 6") with white spines; and fruit of NY12-257, NY12-258, and DMR-NY264 are of medium length (6 to $\left.9^{\prime \prime}\right)$ with white spines.

In the early generations, plants were selected primarily based on resistance, and in later generations, yield and flavor were also considered. Each year, cucumbers were transplanted in July in anticipation of natural downy mildew infection in August. In 2009, 2010, 2011, and 2012, downy mildew arrived in our field sites on 28 Aug., 2 Aug., 6 Aug., and 5 Aug., respectively. Disease spread quickly in all locations and years. Resistant individuals were identified and selected late in the season just before the onset of consistent cold weather to ensure that disease pressure would be long-lasting and severe. High levels of resistance were observed in the $\mathrm{F}_{2}$ and $\mathrm{BC}_{1} \mathrm{~F}_{2}$ generations and maintained through the $\mathrm{F}_{4}$. For susceptible genotypes, disease typically reduced fruit production within 1 week of first disease symptoms and caused complete plant death 2 to 3 weeks later. Resistant lines developed chlorotic lesions, but at a much reduced severity and rate when compared with susceptible lines and control varieties. Additionally, the chlorotic lesions of the resistant lines turned necrotic slowly and resistant lines continued to grow and bear fruit throughout the season until frost.

Field trial-downy mildew resistance. To evaluate the use of the downy mildew resistance in our $\mathrm{F}_{4}$ breeding lines, we trialed these lines against a panel of 17 accessions and cultivars, including those with the highest known levels of resistance to the post-2004 strain of $P$. cubensis. Plants were transplanted in the field on 11 July 2012, and the first symptoms of downy mildew were recorded in the trial on 14 Aug. 2012. The disease spread quickly and uniformly throughout the trial plots. During the disease infection period, symptoms on the most susceptible genotypes in our trial increased exponentially, whereas symptoms of the most resistant genotypes, including our resistant breeding lines, increased gradually and linearly $\left(R^{2}\right.$ of 0.98232 for the most resistant lines not separated by Tukey's HSD). No diseases other than downy mildew were observed in the field.

By 10 Sept. 2012, the genotypes with the highest level of downy mildew-'Picolino', 'WI 2238', 'Fanfare', 'Eureka', 'Cross Country', 'Platinum', 'Straight 8', 'Dasher II', 'Salt \& Pepper', and 'Poinsett 76' - had $90 \%$ or greater diseased leaf area averaged across the three replicated plots. By contrast, the genotypes with the lowest level of disease-NY12-258, NY12-257, NY12-261, NY12-260, and DMR-NY264-had 30\% or less diseased leaf area and DMR-NY264 had only $21.6 \%$ diseased leaf area averaged across the three plots. Representative plots of eight of the trial entries are shown in Figure 3 on 14 Sept., 1 month after disease symptoms were first recorded. By 26 Sept. 2012, the last day of data collection, all plants of 11 cultivars were completely dead: 'Platinum', 'Salt \& Pepper', 'Dasher II', 'Picolino', 'Straight 8', 'Cross Country', 'Fanfare', 'Poinsett 76', 'Eureka', 'WI 2238', and 'WI 2757'. All remaining commercial cultivars and PI accessions had $80 \%$ or greater diseased leaf area with the exception of PI 197088 and 'Ivory Queen', which had 68\% and 75\% diseased leaf area, respectively. The Cornell breeding lines NY12-257, NY12-261, DMRNY264, and NY12-260 had $50 \%$ or less diseased leaf area at $47 \%, 43 \%, 43 \%$, and $37 \%$, respectively. These lines continued to produce green foliage until first frost on 12 Oct. 2012

At the end of the season, AUDPC values summarizing season-long data were calculated and means were separated with Tukey's
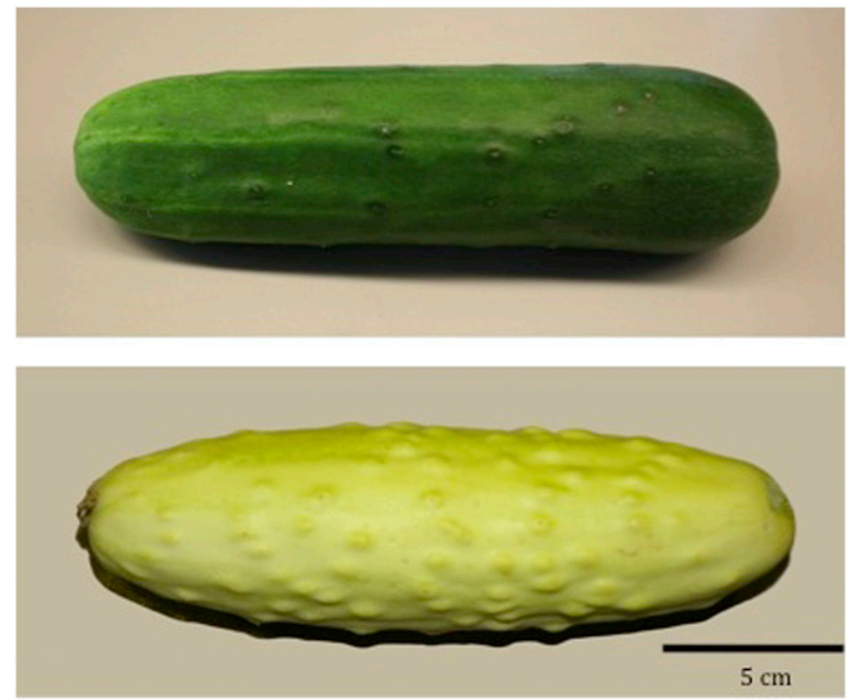

Fig. 2. Cornell downy mildew-resistant breeding lines. Top: DMR-NY264, bottom: NY12-257. The scale is applied to both fruits. 
A
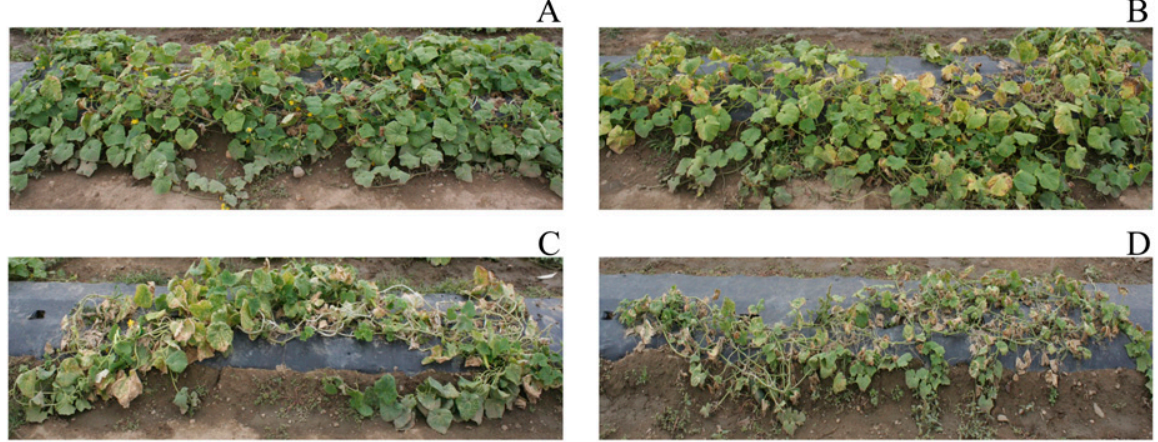

E
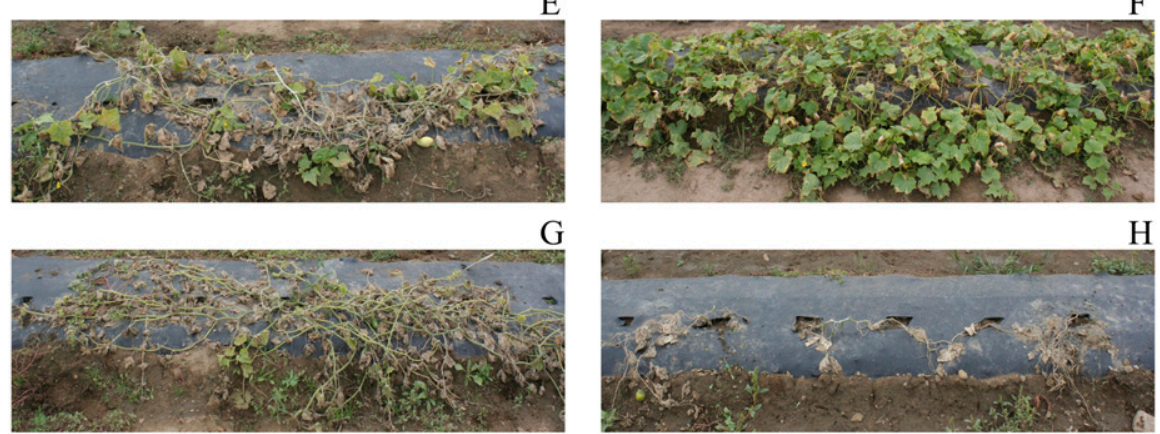

G

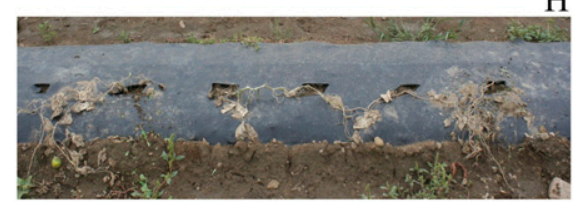

Fig. 3. Pictures of downy mildew-infected cucumber plots, taken 14 Sept. 2012. (A) Cornell $\mathrm{F}_{4}$ breeding line DMR-NY264. (B) Cornell F 4 breeding line NY12-257. (C) 'Ivory Queen', parent to DMR-NY264 and NY12-257. (D) 'Marketmore 97', parent to DMR-NY264. (E) 'Platinum', parent to NY12-257. (F) PI 197088, most resistant PI identified by Call et al. (2012b). (G) WI 2757, top resistant cultigen identified by Call et al. (2012a). (H) 'Picolino', susceptible.

HSD as shown in Table 2. Values varied between 817 for DMR-NY264, the most resistant, to 3618 for 'Picolino', the most susceptible. The four most resistant lines were Cornell breeding lines NY12-257, NY12-260, NY12-261, and DMR-NY264, which were significantly more resistant than all commercial cultivars and PI accessions evaluated except PI 197088 and PI 330628.

Field trial-yield. Yield of Cornell breeding lines was measured against a panel of cultivars and accessions (Table 1). Yield data were divided into two 3-week time periods. The first six data collections were taken at the beginning of the downy mildew infection period (early downy), before disease symptoms had become severe. The last six measurements were taken at the peak of disease infection (late downy). Climate conditions remained very similar between these time periods. Mean air temperatures for the early downy period of 9 Aug. to 29 Aug. were $26.8{ }^{\circ} \mathrm{C}$ high $/ 14.8{ }^{\circ} \mathrm{C}$ low, and mean air temperatures for the late downy period of $30 \mathrm{Aug}$. to 19 Sept. were $25.7{ }^{\circ} \mathrm{C}$ high/ $12.8{ }^{\circ} \mathrm{C}$ low as recorded by the weather monitoring station maintained by the New York State Vegetable Crops Farm in Geneva (<http://www.nysaes. cals.cornell.edu/weather/history $>$ ). During the first week of data collection, fruit were at the harvestable stage for PI 197088, PI 197085, NY12-263, and all commercial cultivars. During the second week, PI 330628, NY12-261, and DMR-NY264 began fruiting. During the third and fourth weeks, NY12-262 and NY12259 , respectively, began fruiting. All remaining Cornell lines started fruiting in the fifth week, except for 12-256, which never produced any fruit.

In the early downy period, the cultivars Ivory Queen, Salt \& Pepper, Dasher II, Eureka, Cross Country, WI 2238, and Poinsett 76 produced the highest yields, as indicated by total weight and total marketable fruit per plant (Table 3). 'Picolino' produced a large number of fruit, but most were scarred and misshapen, primarily because of its extreme susceptibility to downy mildew, even in early weeks. PI 197088 also produced high yields, but because cucumbers from the accession are not palatable, none were considered "marketable." Cornell breeding lines are later-maturing and so produced little during the first few weeks of data collection.

In the late downy period, the Cornell breeding lines DMR-NY264, NY12-262, NY12-261, and NY12-263 produced the highest yields, as indicated by total weight and total marketable fruit per plant (Table 4). PI 197088 also yielded heavily during this period. Fruit production of most commercial cultivars was sparse and many fruits were misshapen as a result of heavy downy mildew infection. Yields of the top-producing Cornell breeding lines in the late downy period were not significantly different from yields of the top-producing commercial cultivars in the early downy period (Table 5).

2012 Winter greenhouse assay. Eight Cornell breeding lines were evaluated for downy mildew resistance against 22 cultivars and PI accessions in a cotyledon assay. RaAUDPC proportions were calculated using the control cultivar that most reduced the $\mathrm{CV}$ of the data,
Table 2. Downy mildew resistance of cucumber lines trialed in Geneva, NY, in Summer 2012. ${ }^{z}$

\begin{tabular}{|c|c|c|}
\hline Genotype & Mean & AUDPC \\
\hline DMR-NY264 & $817^{y}$ & $a^{x}$ \\
\hline NY12-260 & 921 & a \\
\hline NY12-261 & 1063 & a \\
\hline NY12-257 & 1233 & $\mathrm{a}$ \\
\hline NY12-258 & 1251 & $a b$ \\
\hline PI 197088 & 1370 & $a b$ \\
\hline NY12-263 & 1395 & $\mathrm{ab}$ \\
\hline PI 330628 & 1422 & $a b c$ \\
\hline NY12-262 & 1436 & $a b c$ \\
\hline NY12-255 & 1543 & $a b c$ \\
\hline PI 197085 & 2022 & bcd \\
\hline Ivory Queen & 2188 & cde \\
\hline Marketmore 97 & 2200 & cde \\
\hline NY12-256 & 2336 & def \\
\hline NY12-259 & 2502 & defg \\
\hline WI 2757 & 2622 & defgh \\
\hline Poinsett 76 & 2805 & efghi \\
\hline Diva & 2986 & fghij \\
\hline Salt \& Pepper & 3049 & fghij \\
\hline WI 2238 & 3061 & fghij \\
\hline Dasher II & 3094 & fghij \\
\hline Platinum & 3189 & ghij \\
\hline Eureka & 3215 & ghij \\
\hline Cross Country & 3258 & ghij \\
\hline Fanfare & 3378 & hij \\
\hline Straight 8 & 3500 & $\mathrm{ij}$ \\
\hline Picolino & 3618 & $\mathrm{j}$ \\
\hline
\end{tabular}

${ }^{\mathrm{z}}$ Data are from three replications. Analysis of variance $\mathrm{F}$-value $=40.1, \mathrm{MSE}=59,827, \mathrm{df}_{\text {genotype }}=$ $26, \mathrm{df}_{\text {residual }}=53$. Significant at $P<0.0001$.

${ }^{y}$ Calculated means are area under disease progress curve (AUDPC) calculated from percentage of diseased foliar area on a per plot basis. A larger number indicates more disease.

${ }^{x}$ Means in the same column followed by the same letter are not statistically different as determined by Tukey's honestly significant difference $(P=0.05)$ test.

in this case 'Straight 8', using a method described by Yuen and Forbes (Yuen and Forbes, 2009). NY12-257, WI 2238, NY12263, DMR-NY264, and NY21-258 had the lowest levels of disease, although most lines were not significantly different (Table 6).

\section{Discussion}

Cucurbit downy mildew is a serious threat to cucumber production in the eastern United States and around the world. Since 2004, a strain of $P$. cubensis has rendered ineffective the genetic resistance used for decades in most commercial cultivars. Studies over the past few years have identified germplasm with improved levels of resistance (Call et al., 2012b; Criswell, 2008). Nonetheless, high levels of resistance from these new sources have not been incorporated into cultivars to date (Call et al., 2013). For the first time, we report the development of green- and white-skinned cucumber breeding lines that are resistant to the strain(s) of downy mildew currently affecting production in the Northeast.

In a field trial evaluating downy mildew resistance, Cornell breeding lines displayed superior resistance to the most resistant genotypes identified in previous studies. DMRNY264 was the most resistant, and no fewer than five Cornell lines ranked higher than the most resistant accessions identified from the 
Table 3. Yield results for cucumber lines trialed in Geneva, NY, during the early downy mildew period, Summer $2012 .^{z}$

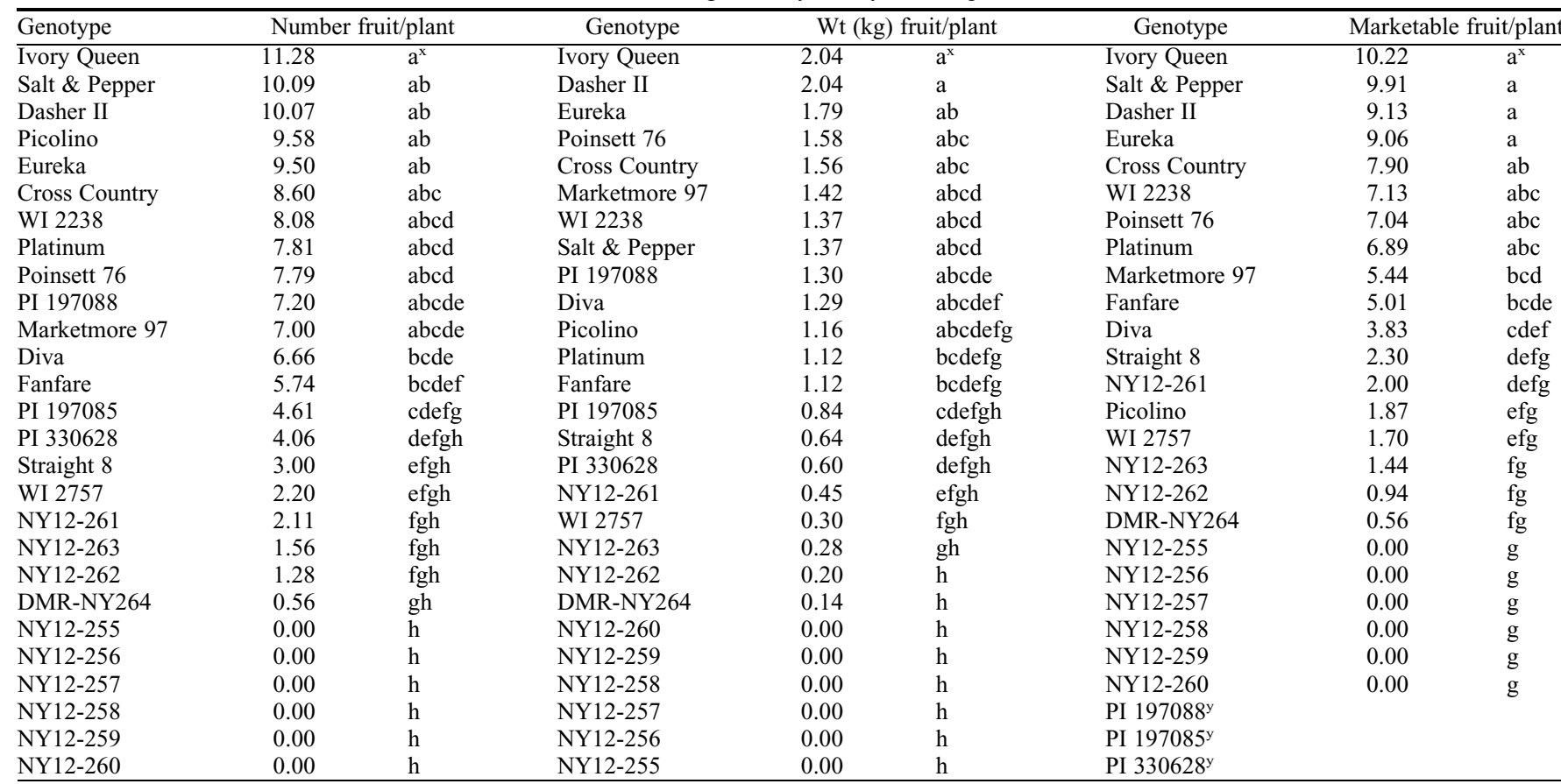

${ }^{2}$ Data were collected six times, twice per week for 3 weeks, starting on 10 Aug. 2012 and ending on 28 Aug. 2012. Data presented indicate average values across replications. Number of fruit/plant analysis of variance (ANOVA) F-value $=23.0, \mathrm{MSE}=1.98, \mathrm{df}_{\text {genotype }}=26, \mathrm{df}_{\text {residual }}=53$. Significant at $P<0.0001$. Weight of fruit/plant ANOVA F-value $=18.2, \mathrm{MSE}=0.078, \mathrm{df}_{\text {genotype }}=26, \mathrm{df}_{\text {residual }}=53$. Significant at $P<0.0001$. Number of Fruit $/$ Plant ANOVA F-value $=32.7, \mathrm{MSE}=$ $1.23, \mathrm{df}_{\text {genotype }}=23, \mathrm{df}_{\text {residual }}=47$. Significant at $P<0.0001$.

"PI 197088, PI 197085, and PI 330628 were excluded from the analysis of marketable fruit, because none of the fruit produced by these accessions was considered "marketable."

${ }^{x}$ Means in the same column followed by the same letter are not statistically different as determined by Tukey's honestly significant difference $(P=0.05)$.

Table 4. Yield results for cucumber lines trialed in Geneva, NY, during the late downy period, Summer 2012.

\begin{tabular}{|c|c|c|c|c|c|c|c|c|}
\hline \multirow{2}{*}{$\begin{array}{l}\text { Genotype } \\
\text { NY12-262 }\end{array}$} & \multicolumn{2}{|c|}{ Number fruit/plant } & \multirow{2}{*}{$\begin{array}{c}\text { Genotype } \\
\text { DMR-NY264 }\end{array}$} & \multicolumn{2}{|c|}{$\mathrm{Wt}(\mathrm{kg})$ fruit $/$ plant } & \multirow{2}{*}{$\begin{array}{c}\text { Genotype } \\
\text { DMR-NY264 }\end{array}$} & \multicolumn{2}{|c|}{ Marketable fruit/plant } \\
\hline & 13.73 & $\mathrm{a}^{\mathrm{x}}$ & & 1.63 & $\mathrm{a}$ & & 6.56 & $\mathrm{a}$ \\
\hline DMR-NY264 & 8.33 & bc & PI 197088 & 1.53 & $a b$ & NY12-261 & 4.28 & $\mathrm{ab}$ \\
\hline NY12-261 & 6.56 & bcd & NY12-261 & 1.23 & $a b c$ & NY12-258 & 4.14 & $a b c$ \\
\hline PI 330628 & 5.94 & bcdef & PI 330628 & 1.13 & $a b c$ & NY12-260 & 3.51 & abcde \\
\hline Ivory Queen & 5.56 & bcdefg & Ivory Queen & 0.88 & bed & Ivory Queen & 2.94 & bcdef \\
\hline NY12-258 & 5.41 & bcdefgh & NY12-258 & 0.73 & cde & NY12-257 & 2.69 & bcdef \\
\hline NY12-257 & 4.06 & cdefghij & Marketmore 97 & 0.57 & cdef & Marketmore 97 & 0.89 & cdef \\
\hline Salt \& Pepper & 3.09 & defghij & NY12-260 & 0.37 & def & Poinsett 76 & 0.74 & def \\
\hline Marketmore 97 & 3.06 & defghij & Dasher II & 0.34 & def & Dasher II & 0.73 & def \\
\hline WI 2757 & 2.80 & defghij & Poinsett 76 & 0.33 & def & Platinum & 0.72 & def \\
\hline Platinum & 2.31 & defghij & WI 2757 & 0.30 & def & Eureka & 0.61 & def \\
\hline Poinsett 76 & 1.94 & defghij & Platinum & 0.29 & def & NY12-255 & 0.44 & ef \\
\hline Dasher II & 1.80 & efghij & Salt \& Pepper & 0.25 & def & Diva & 0.39 & ef \\
\hline NY12-259 & 0.61 & $\mathrm{ij}$ & WI 2238 & 0.10 & ef & NY12-256 & 0.00 & $\mathrm{f}$ \\
\hline Straight 8 & 0.53 & $\mathrm{ij}$ & Fanfare & 0.10 & ef & Picolino & 0.00 & $\mathrm{f}$ \\
\hline Fanfare & 0.50 & $\mathrm{ij}$ & NY12-259 & 0.06 & ef & PI $197088^{y}$ & & \\
\hline NY12-256 & 0.00 & $j$ & NY12-256 & 0.00 & $\mathrm{f}$ & PI $197085^{y}$ & & \\
\hline Picolino & 0.00 & $\mathrm{j}$ & Picolino & 0.00 & $\mathrm{f}$ & PI $330628^{y}$ & & \\
\hline
\end{tabular}

${ }^{\mathrm{z}}$ Data were collected six times, twice per week, starting on 31 Aug. 2012 and ending on 19 Sept. 2012. Data presented indicate average values across replications Number of fruit/plant analysis of variance (ANOVA) F-value $=15.2, \mathrm{MSE}=2.17, \mathrm{df}_{\text {genotype }}=26, \mathrm{df}_{\text {residual }}=53$. Significant at $P<0.0001$. Weight of fruit/plant ANOVA F-value $=17.1, \mathrm{MSE}=0.046, \mathrm{df}_{\text {genotype }}=26, \mathrm{df}_{\text {residual }}=53$. Significant at $P<0.0001$. Number of fruit/plant ANOVA F-value $=11.3, \mathrm{MSE}=1.08$, $\mathrm{df}_{\text {genotype }}=23, \mathrm{df}_{\text {residual }}=47$. Significant at $P<0.0001$.

"PI 197088, PI 197085, and PI 330628 were excluded from the analysis of marketable fruit, because none of the fruit produced by these accessions was considered "marketable."

${ }^{x}$ Means in the same column followed by the same letter are not statistically different as determined by Tukey's honestly significant difference $(P=0.05)$.

USDA collection: PI 197088, PI 197085, and PI 330628 (Call et al., 2012b). Additionally, Cornell lines were more resistant than 'WI

2757' and 'WI 2238', the most resistant cultivars identified in trials held in North Carolina and Michigan (Call et al., 2012a). Cornell breed- ing lines displayed higher resistance than any of the breeding parents. Even after 8 weeks of intense downy mildew pressure, when most 
Table 5. Comparison of top-yielding 'early downy' genotypes and 'late downy' genotypes. '

\begin{tabular}{|c|c|c|c|c|c|}
\hline \multirow{2}{*}{$\begin{array}{l}\text { Genotype } \\
\text { Ivory Queen }\end{array}$} & \multicolumn{2}{|c|}{ Marketable Fruit/Plant } & \multicolumn{2}{|c|}{ Wt (kg)/Plant } & \multirow{2}{*}{$\frac{\text { Disease Period }}{\text { Early }}$} \\
\hline & 10.22 & $\mathrm{a}^{\mathrm{y}}$ & 2.04 & $\mathrm{a}$ & \\
\hline Dasher II & 9.13 & $a b$ & 2.04 & $\mathrm{a}$ & Early \\
\hline Eureka & 9.06 & $\mathrm{ab}$ & 1.79 & $\mathrm{a}$ & Early \\
\hline DMR-NY264 & 6.56 & $a b$ & 1.63 & a & Late \\
\hline NY12-262 & 6.37 & $a b$ & 1.57 & $\mathrm{a}$ & Late \\
\hline NY12-261 & 4.28 & $\mathrm{~b}$ & 1.23 & $\mathrm{a}$ & Late \\
\hline
\end{tabular}

${ }^{\mathrm{z}}$ Weight of fruit/plant analysis of variance $\left(\right.$ ANOVA) F-value $=1.49, \mathrm{MSE}=0.193, \mathrm{df}_{\text {genotype }}=5, \mathrm{df}_{\text {residual }}=$ 12. $P=0.264$. Data presented indicate average values across replications. Marketable fruit/plant ANOVA $\mathrm{F}$-value $=4.68, \mathrm{MSE}=3.20, \mathrm{df}_{\text {genotype }}=5, \mathrm{df}_{\text {residual }}=12$. Significant at $P=0.013$.

${ }^{y}$ Means in the same column followed by the same letter are not statistically different as determined by Tukey's honestly significant difference $(P=0.05)$.

Table 6. RaAUDPC of 30 cucumber lines evaluated in Winter 2013 greenhouse screen for downy mildew resistance. ${ }^{\mathrm{z}}$

\begin{tabular}{|c|c|c|}
\hline \multirow{2}{*}{$\begin{array}{l}\text { Genotype } \\
\text { NY12-257 }\end{array}$} & \multicolumn{2}{|c|}{ Mean RaAUDPC } \\
\hline & $0.00^{\mathrm{y}}$ & $\mathrm{a}^{\mathrm{w}}$ \\
\hline WI $2238^{x}$ & 0.01 & $\mathrm{a}$ \\
\hline DMR-NY264 & 0.03 & $\mathrm{a}$ \\
\hline NY12-263 & 0.03 & a \\
\hline NY12-258 & 0.04 & $\mathrm{a}$ \\
\hline PI 330628 & 0.16 & $\mathrm{ab}$ \\
\hline PI 197088 & 0.18 & $a b c$ \\
\hline Diva & 0.19 & $a b c$ \\
\hline Salt \& Pepper & 0.20 & $\mathrm{abc}$ \\
\hline NY12-252 & 0.25 & abcd \\
\hline NY12-222 & 0.28 & abcd \\
\hline NY12-260 & 0.28 & abcd \\
\hline Ivory Queen & 0.33 & abcd \\
\hline Fanfare & 0.35 & abcd \\
\hline NY12-261 & 0.37 & abcd \\
\hline WI 2757 & 0.39 & abcd \\
\hline Marketmore 76 & 0.47 & abcd \\
\hline Picolino & 0.48 & abcd \\
\hline Dasher II & 0.48 & abcd \\
\hline Platinum & 0.56 & abcd \\
\hline PI 197085 & 0.56 & abcd \\
\hline Eureka & 0.60 & abcd \\
\hline Marketmore $80 \mathrm{Bw}$ & 0.62 & abcd \\
\hline SV3462CS & 0.70 & abcd \\
\hline Poinsett 76 & 0.71 & abcd \\
\hline Marketmore 97 & 0.86 & bcd \\
\hline SV4719CS & 0.89 & bcd \\
\hline PI 197087 & 0.96 & bcd \\
\hline Straight 8 & 0.99 & $\mathrm{~cd}$ \\
\hline Cross Country & 1.04 & $\mathrm{~d}$ \\
\hline
\end{tabular}

${ }^{\mathrm{z}}$ Analysis of variance $\mathrm{F}$-value $=4.52, \mathrm{MSE}=$ $0.0627, \mathrm{df}_{\text {genotype }}=29, \mathrm{df}_{\text {residual }}=59$. Significant at $P<0.0001$.

${ }^{\mathrm{y}}$ Means are RaAUDPC, a proportion representing the area under disease progress curve (AUDPC) calculated from percentage diseased cotyledon leaf area, standardized to control variety, 'Straight 8'.

${ }^{x}$ Data are from three replications, except 'WI 2238', which is replicated twice.

wMeans in the same column followed by the same letter are not statistically different as determined by Tukey's honestly significant difference $(P=0.05)$.

cultivars had been dead for 1 month, the top Cornell lines were still green with less than $50 \%$ diseased leaf area and very few necrotic regions.

The resistance in Cornell lines is likely to be oligogenic or multigenic in nature and comprised of alleles that contribute to resistance in an additive manner or when present in a homozygous recessive state. This hypothesis originates from several lines of evidence, namely that informally observed $\mathrm{F}_{1}$ individuals lacked the same level of resistance as the $\mathrm{F}_{2}$ and subsequent generations, that the resistance of Cornell lines was not total, as is commonly observed with cultivars containing single gene resistance (Kelly and Vallejo, 2006), and that levels of resistance in Cornell lines exceeded that of either parent in their pedigrees, which suggests that unique, non-complementary alleles contributing to resistance were introduced from both parents.

Results from the greenhouse assay, which incorporated a broader mixture of pathogen isolates collected in 2012, were largely consistent with the field trial excepting increased variability, which was likely the result of the smaller area measured on a group of cotyledons compared with whole plant plots. Some changes in ranking may have been influenced by the more representative inoculum or the greater susceptibility to downy mildew of cotyledons as compared with true leaves (Lebeda and Cohen, 2011). Interestingly, PI 197087, which is an original source of downy mildew resistance, was highly susceptible in the greenhouse assay. This is consistent with the observation that cultivars with resistance derived from PI 197087 are not resistant in field trials (Call et al., 2013; Kozik et al., 2012).

The downy mildew-resistant Cornell breeding lines yielded very well during periods of disease pressure. Cornell lines are latermaturing than most commercial cultivars, which in the early downy period had higher yields than any of the Cornell lines. Once the top Cornell lines started fruiting and disease was prevalent, however, they greatly outperformed all cultivars. During the late downy period, the Cornell line DMR-NY264 produced nine and 10 times as many marketable fruits as 'Dasher II' and 'Eureka', cultivars known to be high-yielding and regarded as the most widely grown slicing and pickling cucumbers, respectively. Additionally, the productivity of the Cornell breeding lines during the late downy period was comparable to the productivity of the commercial cultivars in the early downy period. The decline of commercial cultivars during the late downy period was the result of disease rather than general plant senescence given that the climate was conducive for growth and that most cultivars can physiologically produce consistently for up to 6 weeks of 15 harvests or more when fruits are harvested regularly (Schultheis et al., n.d.; Stivers, n.d.), even if large-scale growers rarely harvest for this length of time in practice.

\section{Conclusion}

Our breeding lines represent a valuable resource for breeders and farmers alike. After several generations of stringent selection for downy mildew resistance, the resistance in these lines appears to be fixed. Additionally, several of the lines, although late, have good yields during disease pressure. Particularly DMR-NY264 had consistently high levels of resistance and yielded well in all evaluations. DMR-NY264 has commercial value for sustaining fresh-market production during periods of downy mildew pressure if paired with other cultivars for earlier harvests

\section{Literature Cited}

Barnes, W.C. 1948. The performance of Palmetto, a new downy mildew-resistant variety. Proc. Amer. Soc. Hort. Sci. 51:437-444.

Barnes, W.C. 1961. Multiple disease resistant cucumbers. Proc. Amer. Soc. Hort. Sci. 77:417-423.

Barnes, W.C., C.N. Clayton, and J.M. Jenkins, Jr. 1946. The development of downy mildewresistant cucumbers. Proc. Amer. Soc. Hort. Sci. 47:357-360.

Barnes, W.C. and W.M. Epps. 1954. An unreported type of resistance to cucumber downy mildew. Plant Dis. Rptr. 38:620.

Boodley, J.W. and R. Sheldrake, Jr. 1982. Cornell peat-lite mixes for commercial plant growing. Cornell Coop. Ext. Bul. 43.

Call, A.D. 2012. Inheritance of resistance to downy mildew in cucumber (Cucumis sativus L.) PI 197088 and effect of interaction of host plant resistance, fungicides, and environment on severity of downy mildew on cucumber. $\mathrm{PhD}$ diss., North Carolina State, Univ., Raleigh, NC.

Call, A.D., A.D. Criswell, T.C. Wehner, K. Ando, and R. Grumet. 2012a. Resistance of cucumber cultivars to a new strain of cucurbit downy mildew. HortScience 47:171-178.

Call, A.D., A.D. Criswell, T.C. Wehner, U. Klosinska, and E.U. Kozik. 2012b. Screening cucumber for resistance to downy mildew caused by Pseudoperonospora cubensis (Berk. and Curt.) Rostov. Crop Sci. 52:577-592.

Call, A.D. and T.C. Wehner. 2010. Search for higher resistance to the new race of downy mildew in cucumber, p. 112-115. In: Thies, J.A., S. Kousik, and A. Levi (eds.). Proc. Cucurbitaceae 2010, Charleston, SC.

Call, A.D., T.C. Wehner, G.J. Holmes, and P.S. Ojiambo. 2013. Effects of host plant resistance and fungicides on severity of cucumber downy mildew. HortScience 48:53-59.

Cavatorta, J., G. Moriarty, M. Glos, M. Henning, M. Kreitinger, M. Mazourek, and H. Munger. 2012. 'Salt and Pepper': A disease-resistant cucumber inbred. HortScience 47:427-428.

Cavatorta, J., G. Moriarty, M. Henning, M. Glos, M. Kreitinger, H.M. Munger, and M. Jahn. 2007'Marketmore 97': A monoecious slicing cucumber inbred with multiple disease and insect resistances. HortScience 42:707-709.

Clark, R., A. Gabert, H. Munger, J. Staub, and T. Wehner. 1996. Cucumber. Cucumber Germplasm Committee.

Cochran, F.D. 1937. Breeding cucumbers for resistance to downy mildew. Proc. Amer. Soc. Hort. Sci. 35:541-543. 
Cohen, Y. and H. Eyal. 1977. Growth and differentiation of sporangia and sporangiophores of Pseudoperonospora cubensis on cucumber cotyledons under various combinations of light and temperature. Physiol. Plant Pathol. 10:93-103.

Colucci, S.J. and G.J. Holmes. 2010. Downy mildew of cucurbits. Plant Health Instructor.

Colucci, S.J., T.C. Wehner, and G.J. Holmes. 2006. The downy mildew epidemic of 2004 and 2005 in the eastern United States, p. 403-411. In: Holmes, G.J. (ed.). Proc. Cucurbitaceae 2006, Raleigh, NC.

Criswell, A. 2008. Screening cucumber (Cucumis sativus) for resistance to downy mildew (Pseudoperonospora cubensis). MS thesis, North Carolina State, Raleigh, NC.

Criswell, A.D., T.C. Wehner, U. Klosinska, and E. Kozik. 2008. Use of sporulation and other leaf and vine traits for evaluation of resistance to downy mildew in cucumber, p. 433-440. In: Pitrat, M. (ed.). Proc. Cucurbitaceae 2008.

de Mendiburu, F. 2013. agricolae: Statistical Procedures for Agricultural Research. R package version 1.1-4. 6 June 2013. <http://CRAN.Rproject.org $/$ package $=$ agricolae $>$.

Duran, M.Y., M. Gretenkort, A. Grit, J. King, H. van Kooten, I. Peck, N.V. Shetty, and B. Sipeyre. 2009. Downy mildew resistant cucumber plants. Patent US20090265803 A1. USPTO. Seminis Vegetable Seeds, Inc., USA.

FAOSTAT. 2013. Vegetables and melons area harvested-2011. FAO. 24 May 2013. <http:// faostat.fao.org/site/567/DesktopDefault.aspx? PageID $=567$ \#ancor $>$.

Hansen, J.G., M. Koppel, A. Valskyte, I. Turka, and J. Kapsa. 2005. Evaluation of foliar resistance in potato to Phytophthora infestans based on an international field trial network. Plant Pathol. 54:169-179.

Holmes, G., T. Wehner, and A. Thornton. 2006. An old enemy re-emerges. Amer. Veg. Grower 54:14-15.

Jenkins, J.M., Jr. 1942. Downy mildew resistance in cucumbers. J. Hered. 33:35-38.

Kelly, J.D. and V. Vallejo. 2006. QTL analysis of multigenic disease resistance in plant breeding. In: Tuzun, S. and E. Bent (eds.). Multigenic and induced systemic resistance in plants. Springer Science + Business Media, Inc., New York, NY.

Klosinska, U., E.U. Kozik, A. Call, and T.C. Wehner. 2010. New sources of resistance to downy mildew in cucumber, p. 135-138. In: Thies, J.A., S. Kousik, and A. Levi (eds.). Proc. Cucurbitaceae 2010, Charleston, SC.
Kozik, E.U., U. Klosinska, A.D. Call, and T.C. Wehner. 2012. Heritability and genetic variance estimates for resistance to downy mildew in cucumber accession Ames 2354. Crop Sci. 53:177-182.

Lebeda, A. 1992. Screening of wild Cucumis species against downy mildew (Pseudoperonospora cubensis) isolates from cucumbers. Phytoparasitica 20:203-210.

Lebeda, A. and Y. Cohen. 2011. Cucurbit downy mildew (Pseudoperonospora cubensis)Biology, ecology, epidemiology, host-pathogen interaction and control. Eur. J. Plant Pathol. 129:157-192.

Lebeda, A., J. Pavelkova, J. Urban, and B. Sedlakova. 2011. Distribution, host range and disease severity of Pseudoperonospora cubensis on cucurbits in the Czech Republic. J. Phytopathol. 159:589-596.

Ma, Q. and H. Cui. 1995. Histopathology of cucumber resistance to downy mildew. Cucurbit Genet. Coop. Rpt. 18:26-28.

McGrath, M.T., G.M. Fox, and S. Menasha. 2010. Downy mildew susceptibility of cucumber varieties, New York, 2009. Midwest Veg. Trial Rpt.

Munger, H.M. 1993. Breeding for viral disease resistance in cucurbits. In: Kyle, M. M. (ed.). Resistance to viral diseases of vegetables: Genetics and breeding. Timber Press, Portland, OR.

Neykov, S. and D. Dobrev. 1982. Introduced cucumber cultivars relatively resistant to Pseudoperonospora cubensis in Bulgaria. Acta Hort. 220:115-119.

Nusbaum, C.J. 1944. The seasonal spread and development of cucurbit downy mildew in the Atlantic coastal states. Plant Dis. 28:82-85.

Palti, J. and Y. Cohen. 1980. Downy mildew of cucurbits (Pseudoperonospora cubensis): The fungus and its hosts, distribution, epidemiology and control. Phytoparasitica 8:109-147.

Peterson, C.E. 1975. Plant introductions in the improvement of vegetable cultivars. HortScience 10:575-579.

Peterson, C.E., J.E. Staub, M. Palmer, and L. Crubaugh. 1985. Wisconsin 2843, a multiple disease resistant cucumber population. HortScience 20:309-310.

Peterson, C.E., J.E. Staub, P.H. Williams, and M.J. Palmer. 1986. Wisconsin 1983 cucumber. HortScience 21:1082-1083.

Peterson, C.E., P.H. Williams, M. Palmer, and P. Louward. 1982. Wisconsin 2757 cucumber. HortScience 17:268.

R Core Team. 2013. R: A language and environment for statistical computing. R Foundation for Statistical Computing, Vienna, Austria. 24 May $2013<$ http://www.R-project.org/>.

Savory, E.A., L.L. Granke, L.M. QuesadaOcampo, M. Varbanova, M.K. Hausbeck, and B. Day. 2011. The cucurbit downy mildew pathogen Pseudoperonospora cubensis. Mol. Plant Pathol. 12:217-226.

Schultheis, J.R., C.W. Averre, M.D. Boyette, E.A. Estes, G.J. Holmes, D.W. Monks, and K.A. Sorensen. n.d. Commercial production of pickling and slicing cucumbers in North Carolina. North Carolina State Univ. Coop. Ext. Serv.

Sitterly, W.R. 1972. Breeding for disease resistance in cucurbits. Annu. Rev. Phytopathol. 10:471-490.

Stewart, F.C. 1897. The downy mildew of cucumber; what it is and how to prevent it. New York Ag. Expt. Sta. Bul. 119.

Stivers, L. n.d. Crop profile: Cucumbers in New York. Cornell Coop. Ext.

Thomas, C.E. 1996. Downy mildew. In: Zitter, T.A., D.L. Hopkins, and C.E. Thomas (eds.). Compendium of cucurbit diseases. The Amer. Phytopathol. Soc., St. Paul, MN.

U.S. Department of Agriculture. 2008. Cucumbers: U.S. Import-eligible countries; world production and exports. 24 May 2013. <http://www. ers.usda.gov/data-products/phytosanitaryregulation.aspx\#.UZpg2it34zQ>. U.S. Dept. Agr., Washington, DC.

U.S. Department of Agriculture. 2013. Vegetables: 2012 summary. U.S. Dept. Agr., Washington, DC.

van Vliet, G.J.A. and W.D. Meysing. 1974. Inheritance of resistance to Pseudoperonospora cubensis Rost. in cucumber (Cucumis sativus). Euphytica 23:251-255.

Wehner, T.C. and N.V. Shetty. 1997. Downy mildew resistance of the cucumber germplasm collection in North Carolina field tests. Crop Sci. 37:1331-1340.

Weng, Y. 2009. 2008 public sector cucumber research priority survey. Cucurbit Gen. Coop. Rpt. 31-32:1-4.

Yuen, J.E. and G.A. Forbes. 2009. Estimating the level of susceptibility to Phytophthora infestans in potato genotypes. Phytopathology 99:782786.

Zhang, S.P., M.M. Liu, H. Miao, S.Q. Zhang, Y.H. Yang, B.Y. Xie, T.C. Wehner, and X.F. Gu. 2013. Chromosomal mapping and QTL analysis of resistance to downy mildew in Cucumis sativus. Plant Dis. 97:245-251. 